\title{
The anti-tumoral effects of different local anesthetics on human endometrial carcinoma cell line: An in-vitro study
}

\author{
Erel Varlik K. ${ }^{1}$, Yenisey Cigdem ${ }^{2}$ \\ ${ }^{1}$ Department of Anaesthesiology, Medical Faculty, Adnan Menderes University, Aydin, Turkey \\ ${ }^{2}$ Department of Clinic Biochemistry, Medical Faculty, Adnan Menderes University, Aydin, Turkey
}

Received: 2020-06-18.

Accepted: 2020-07-14

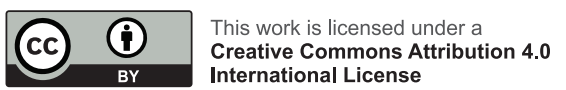

J Clin Med Kaz 2020; 5(59):28-33

Corresponding author:

Erel Varlik K.

E-mail: varlik.erel@gmail.com

\section{Abstract}

Background: There is accumulating evidence on the inhibitory effect of local anesthetic agents on metastasis and tumor recurrence on various cancer types. In this study, we aimed to test the effects of lidocaine, bupivicaine and prilocaine on cellular viability and apoptosis on human endometrial adenocarcinoma cell lines (Ishikawa cells).

Material and methods: Human Endometrial adenocarcinoma cells (Ishikawa cells) were exposed to different concentrations of local anesthetic agents for 24,48 , and 72 hours. The cell viability assay was performed via MTT and concentrations corresponding to 50\% effective concentration (EC50) of cells were determined for each agent. Apoptosis was evaluated via commercial Biocolor ApoPercentage assay.

Results: All of the three local anesthetics reduced the amount of viable tumor cells in a dose-dependent manner. The EC50 values (mM) at 24,48 and $72 \mathrm{~h}$ incubation periods were 11.67, 1.915, 2.114 for lidocaine $11.4,5.21,3.12$ for bupivacaine $7.64 \mathrm{mM}, 7.3 \mathrm{mM}$, and $2.83 \mathrm{mM}$, for prilocaine respectively.

Conclusion: Lidocaine, bupivacaine, and prilocaine have antitumoral effects on Ishikawa cell lines. All of the tested agents induced apoptosis and necrosis at high concentrations in a dose dependentmanner.

Key words: lidocaine, bupivacaine, prilocaine, Ishikawa cell lines, local anesthetics, cancer surgery, metastasis

The Glossary of Terms: Human Endometrial adenocarcinoma cells (Ishikawa cells), 50\% effective concentration (EC50) Local anesthetics (LA), the optical density (OD)

Key points:

Question: Is there three anti tumoral effects of different local anesthetics (lidocaine, bupivacaine, prilocaine) on Ishikawa Cell?

Findings: All three substances (lidocaine, bupivacaine, prilocaine) inhibited the viability and all of substances led apoptosis on Ishikawa cell.

Meaning: This study has shown that three commonly used local anesthetic drugs (lidocaine, bupivacaine, prilocaine) have antitumoral effects on Ishikawa cells in-vitro.

\section{Introduction}

Local anesthetics (LA) are commonly used in procedures requiring general, regional and local anesthesia for the interventional and surgical treatment of cancer. There are many other pharmacological effects of LA in addition to the analgesic and antiarrhythmic effects of local anesthetics [1,2]. Retrospective studies have demonstrated that the use of certain anesthetic agents may reduce the risk of metastasis, cancer recurrence and overall survival at the postoperative period [3-6]. Local anesthetics such as lidocaine might exert beneficial effects in the treatment of cancer by inhibition of cell proliferation, invasion, and migration which are essential in angiogenesis and tumor metastatis [7-9]. Commonly employed local anesthetics including bupivacaine and prilocaine have also been shown to trigger apoptosis in a variety of tumor cells [10-12]. Therefore, apoptosis is suggested to play an important role in the local anestheticinduced cell toxicity in tumor cells [12-14]. 
In this study, we aimed to investigate the anti-tumoral effects of lidocaine, bupivacaine and prilocaine in human endometrial cancer cells (Ishikawa cells). To our knowledge, this is the first study to investigate the anti-tumoral effects of these agents on Ishikawa cells. We hypothesized that these local anesthestic agents might induce apoptosis and reduce the viability of Ishikawa cells in vitro.

\section{Material and methods Reagents}

Commercially avaliable lidocaine (L1026), bupivacaine (606189) and prilocaine (P2939000) were obtained from Sigma-Aldrich. Different concentrations of LAs were prepared using serum-free medium. All of the solutions were prepared immediately prior to use. For cell viability and apoptosis, the analysis concentrations were chosen as clinically achievable plasma levels.

\section{Cell Culture}

Ishikawa cell lines were established an endometrial adenocarcinoma. The cells induced well differentiated adenocarcinoma in athymic nude mice. Estrogen and progesterone receptors were demonstrated both in cell culture and in induced tumours and taken from Adnan Menderes University Science and Technology Center (BILTEM) cell line stocks. Cells were maintained in phenol red Dulbecco's Modified Eagle's Medium: nutrient mixture F12 (DMEM/F12, Lonza, Belgium) and supplemented with 10\% fetal bovine serum (PAA, France), 2 mM of l-glutamine (Lonza, Belgium), penicillin (100 $\mathrm{U} / \mathrm{mL})$, and streptomycin (100 $\mu \mathrm{g} / \mathrm{m})$ (Lonza, Belgium), $1 \%$ Non-Essentials amino acids (Sigma-Aldrich). Ishikawa cells were cultured at $37^{\circ} \mathrm{C}$ in a $\mathrm{CO} 2$ atmosphere $(5 \%)$ and maintained in monolayer culture. Experiments were performed when cells reached $\sim 80-90 \%$ confluence.

\section{Measurement of Cell Viability}

Cell viability was assayed via commercial MTT Cell Viability Kit (Biotium, 3159 Corporate Place, Hayward, CA 94545, Cat No: 30006). The antiproliferative and cytotoxic effects of lidocaine, bupivacaine and prilocaine in human endometrial adenocarcinoma cells were assessed using commercial MTT assay (Biotium (Biotium Co., 3159 Corparate Place, Hayward CA 94545, USA. Catalog Number: 30006). Briefly, Ishikawa cells were seed in 96 well plates $(10000$ cells per well) in $100 \mu \mathrm{L}$ growth medium. 24 hours after seeding, we aspirated the growth medium, added $100 \mu \mathrm{l}$ fresh serum-free DMEM/F12 including 1, 10, 20, 30, $50 \mathrm{mM}$ lidocaine, 0.02, 2, 12, 14, $17 \mathrm{mM}$ bupivacaine and 2, 12, 50, 60, $80 \mathrm{mM}$ prilocaine. After treated with LAs for 24,48 and 72 hours, the medium was aspirated and fresh $10 \mu \mathrm{L}$ MTT solutions (ready in commercial kit) in $90 \mu \mathrm{L}$ serum-free DMEM/F12 medium was added into each well, and cells were incubated for $4 \mathrm{~h}$ at $37^{\circ} \mathrm{C}$ at $5 \% \mathrm{CO} 2$ incubator. Finally, the MTT containing medium was removed and $200 \mu \mathrm{L}$ DMSO (dimethyl sulfoxide) was added per well to dissolve the formazan crystals and wells were incubated on a shaker for 10-15 minutes. The optical density (OD) was measured using BİOTEK LX 800 at wave length $570 \mathrm{~nm}$. The percentage of viability was calculated via the following equation: Viability $(\%)=(\mathrm{OD}$ treatment group/ OD control group)x 100 .

\section{Apoptosis assay}

Ishikawa cells which treated in different doses of LAs were used for apoptosis assay. Commercial Biocolor ApoPercentage apoptosis kit (Biocolor; www.biocolor.co.uk) were used. Cells were seeded in 96 well plates (30.000 cell per well) in $200 \mu \mathrm{l}$ culture medium. After 24 hours incubation period, at $37^{\circ} \mathrm{C} / 5 \%$ $\mathrm{CO} 2$ until confluence was reached $(\sim 80-90 \%)$ incubation medium was removed and cells were rinsed in fresh medium. Then, LAs were added into each well in culture medium at 1/10/20/30/50 mM lidocaine, 0.02/2/12/14/17 mM bupivacaine and $2 / 12 / 50 / 60 / 80 \mathrm{mM}$ prilocaine concentrations. The Ishikawa cell including only growth medium was used as control. After 24,48 and $72 \mathrm{~h}$ incubation period, the medium was aspirated from the cells to preserve floating cells. $100 \mu \mathrm{l} /$ well fresh culture medium containing $5 \mu \mathrm{l}$ APOPercentage Dye and the agents were added into the wells, 30 minutes prior to incubation. After incubating the plates for the 30 more minutes, we decanted the culture medium/dye mixture, and gently washed the cells twice with $200 \mu \mathrm{l} /$ well using DPBS. As soon as the wells were washed, the plates were visualized under inverted microscope and photographs were taken. For colorimetric determination after thoroughly washing the cells, $100 \mu \mathrm{l} /$ well APOPercentage Dye release reagent were added and the plates were shaked gently for $10 \mathrm{~min}$, then the absorbance was measured via BİOTEK LX 800 at $550 \mathrm{~nm}$.

\section{Statistical analysis}

All experiments were performed at least for triple times. IBM SPSS Statistics 25 software was used for statistical analysis. Shapiro Wilk test was implemented to check normality assumption. Statistical analysis was performed by using nonparametric Mann Whitney U Test, since the variables did not show a normal distribution. Hypothesis tests were performed as two-sided at $\alpha=0.05$ significance level. The median $50 \%$ effective concentration (EC50) values for three agents were calculated using the probit method of Miller and Tainter.

\section{Results} Viability

Effects of Lidocaine, Bupivacaine, and Prilocaine on Cell

The viability of Ishikawa cells was determined after incubation with lidocaine, bupivacaine prilocaine and at serially diluted concentrations for 24, 48 and 72 hours. Lidocaine, bupivacaine and prilocaine were inhibited the growth of Ishikawa cells in a dose- and time-dependent manner (Figure 1; $\mathrm{p}<0.001$ ). The percentages of cell death (calculated for 24, 48, and 72 hours) were given in Table 1 .

Figure 1 - Effects of lidocaine, bupivacaine, and prilocaine on endometrial cancer cell viability in different time zone.

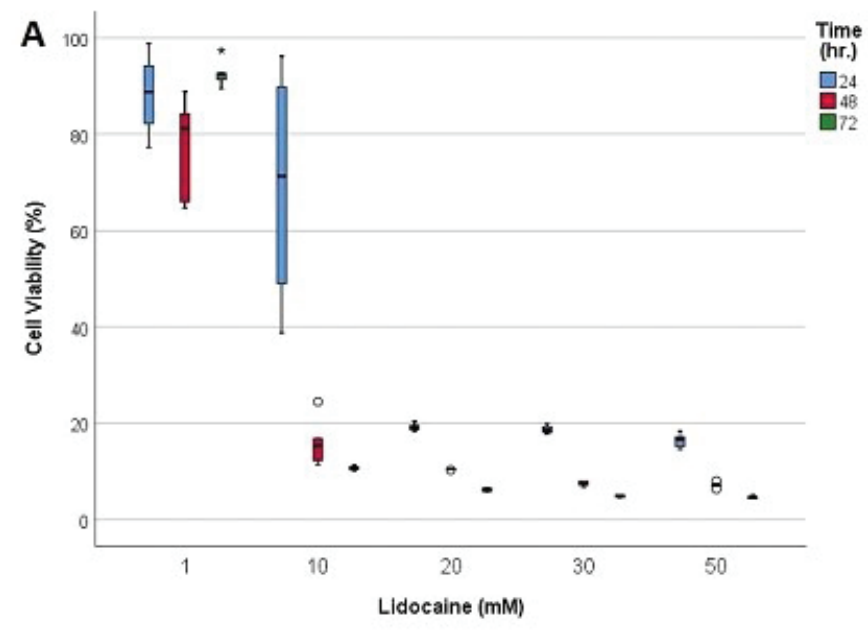




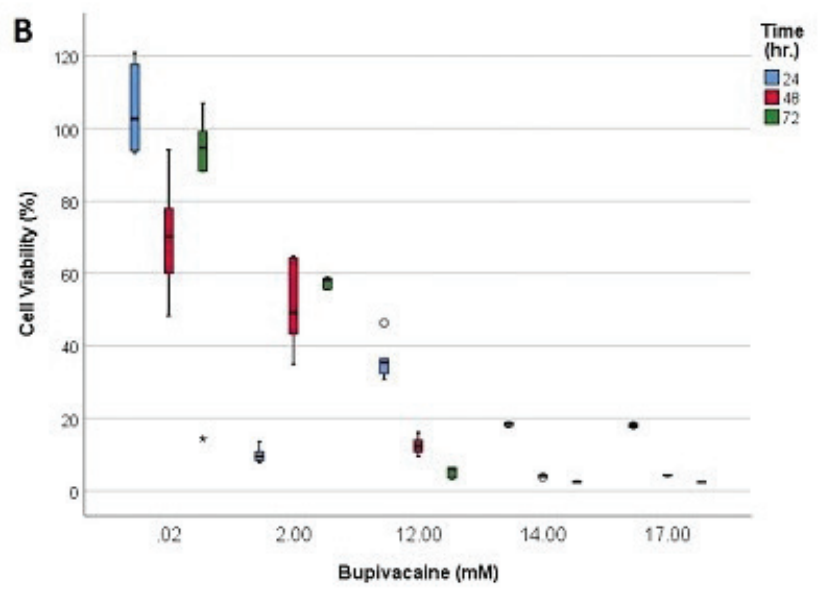

A

\begin{tabular}{llll}
\hline $\begin{array}{l}\text { Lidocaine } \\
(\mathrm{mM})\end{array}$ & $24 \mathrm{~h}$ & $48 \mathrm{~h}$ & $72 \mathrm{~h}$ \\
1 & $88.76 \pm 7.81$ & $81.15 \pm 10.14$ & $92.49 \pm 2.62$ \\
10 & $71.28 \pm 23.81$ & $15.31 \pm 4.66$ & $10.65 \pm 0.4$ \\
20 & $19.1 \pm 0.72$ & $10.48 \pm 0.09$ & $6.33 \pm 0.34$ \\
30 & $18.51 \pm 0.76$ & $7.37 \pm 0.51$ & $4.94 \pm 0.2$ \\
\hline 50 & $16.62 \pm 1.38$ & $7.12 \pm 0.54$ & $4.49 \pm 0.27$ \\
\hline
\end{tabular}

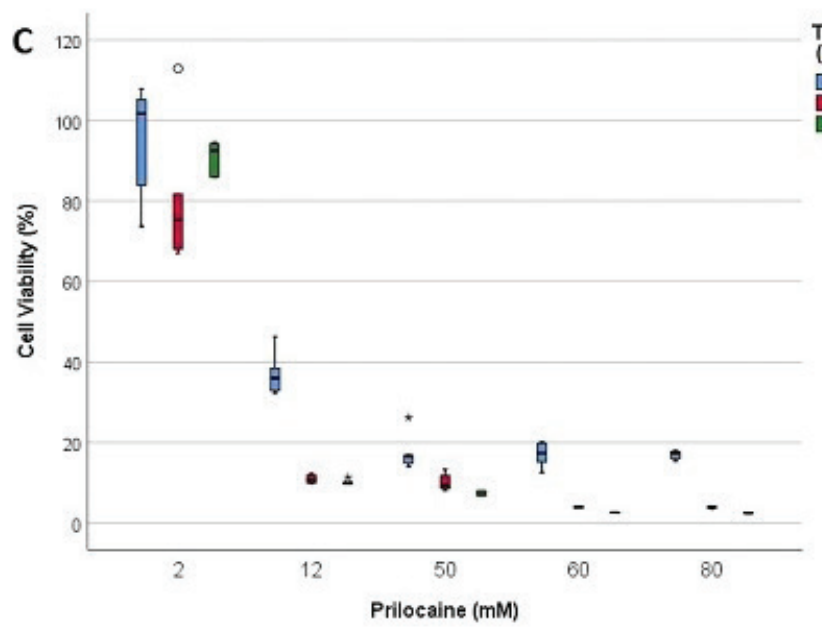

$\underline{B}$

\begin{tabular}{llll}
\hline $\begin{array}{l}\text { Bupivacaine } \\
(\mathrm{mM})\end{array}$ & $24 \mathrm{~h}$ & $48 \mathrm{~h}$ & $72 \mathrm{~h}$ \\
0.02 & $105.16 \pm 12.27$ & $70.11 \pm 15.72$ & $83.04 \pm 14.25$ \\
2 & $96.88 \pm 5.23$ & $50.9 \pm 11.86$ & $57.48 \pm 1.56$ \\
12 & $36.07 \pm 2.1$ & $12.48 \pm 2.39$ & $5.3 \pm 1.52$ \\
14 & $18.39 \pm 0.62$ & $4.06 \pm 0.16$ & $2.45 \pm 0.11$ \\
17 & $18.01 \pm 0.67$ & $4.28 \pm 0.22$ & $2.37 \pm 0.03$ \\
$\mathrm{C}$ & & & \\
\hline $\begin{array}{l}\text { Prilocaine } \\
(\mathrm{mM})\end{array}$ & $24 \mathrm{~h}$ & $48 \mathrm{~h}$ & $72 \mathrm{~h}$ \\
2 & $95.64 \pm 13.74$ & $80.03 \pm 17.06$ & $90.9 \pm 4.0$ \\
12 & $36.99 \pm 5.23$ & $10.89 \pm 1.03$ & $10.12 \pm 0.63$ \\
50 & $17.53 \pm 4.41$ & $10.05 \pm 2.06$ & $7.25 \pm 0.58$ \\
60 & $17.04 \pm 2.88$ & $3.96 \pm 0.24$ & $2.59 \pm 0.047$ \\
80 & $16.99 \pm 1.07$ & $3.87 \pm 0.19$ & $2.47 \pm 0.06$
\end{tabular}

Figure 2 - Effects of local anesthetics on the growth of endometrial cancer cells. Cell viability was determined by MTT assays in Ishikawa cell lines treated with lidaocaine, bupivacaine, and prilocaine for 24,48 and 72 hours. All values are expressed mean \pm SD (ANOVA; $p<0.0001$ and Kruskal-Wallis Test; $p<0.0001$ ).

A

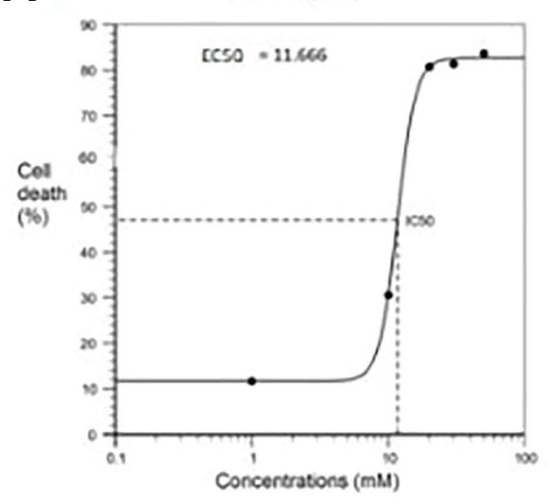

B

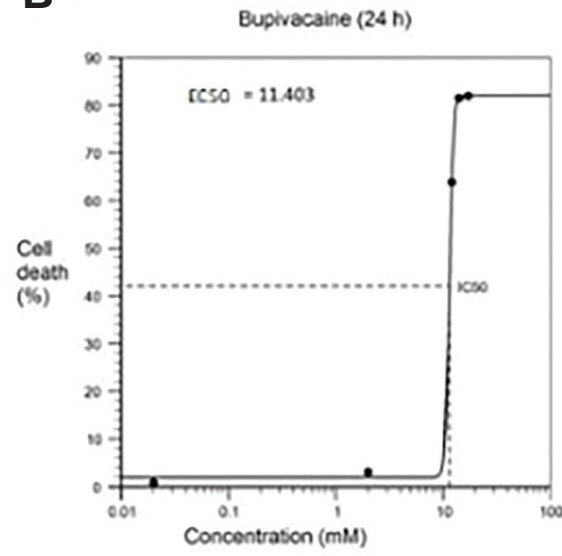

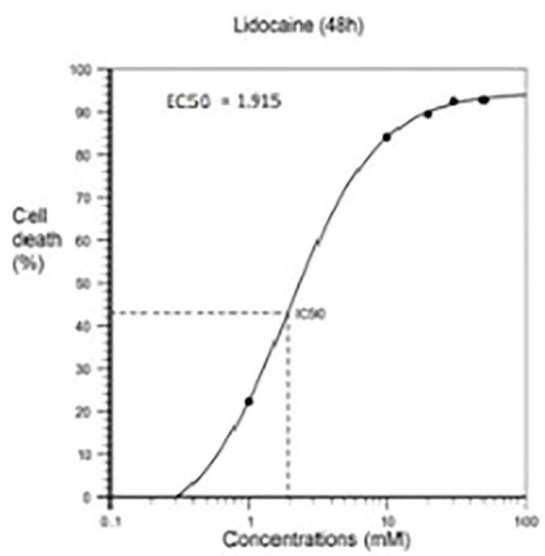
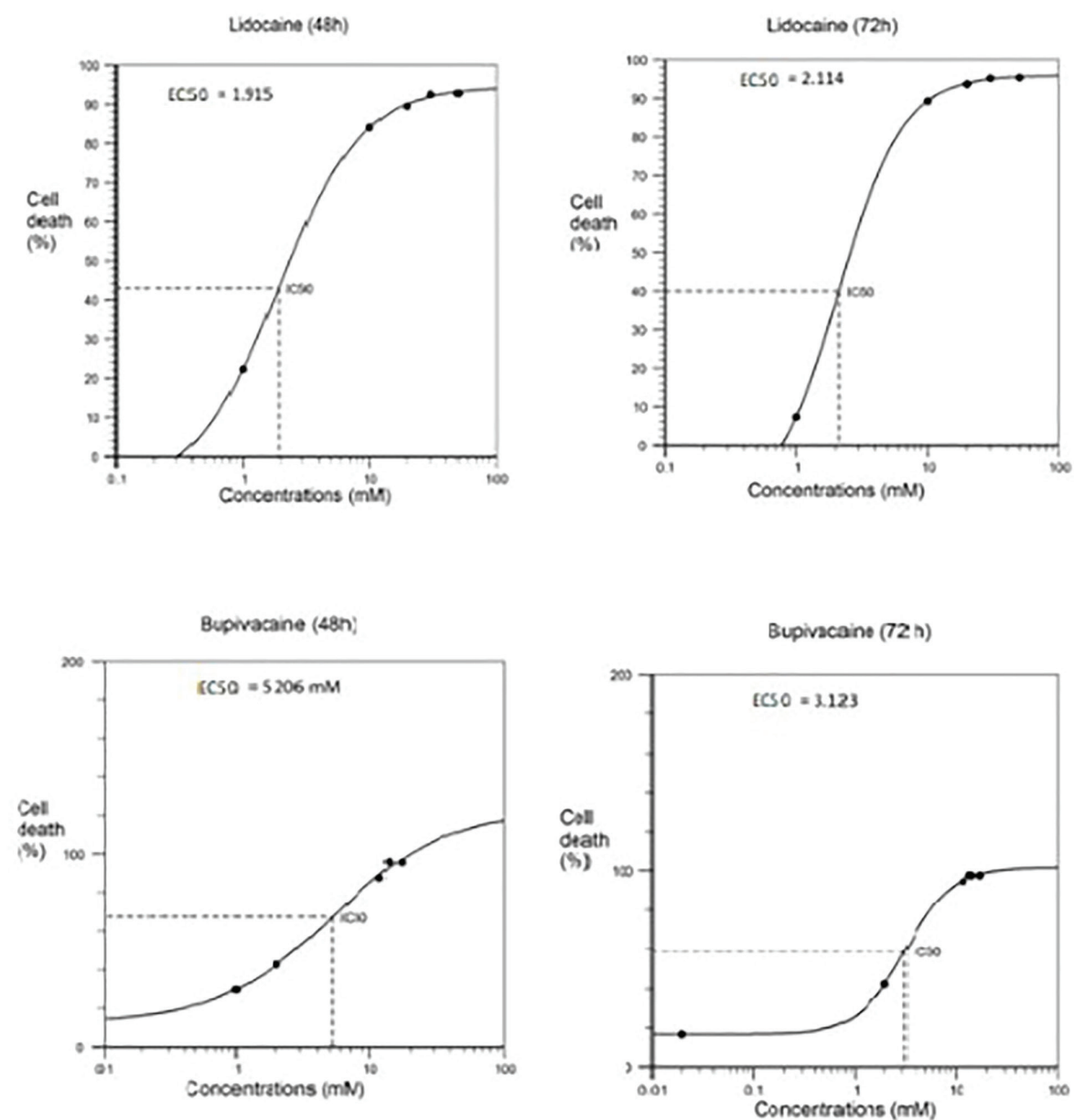

Journal of Clinical Medicine of Kazakhstan: Volume 5, Number 59, Issue 2020 

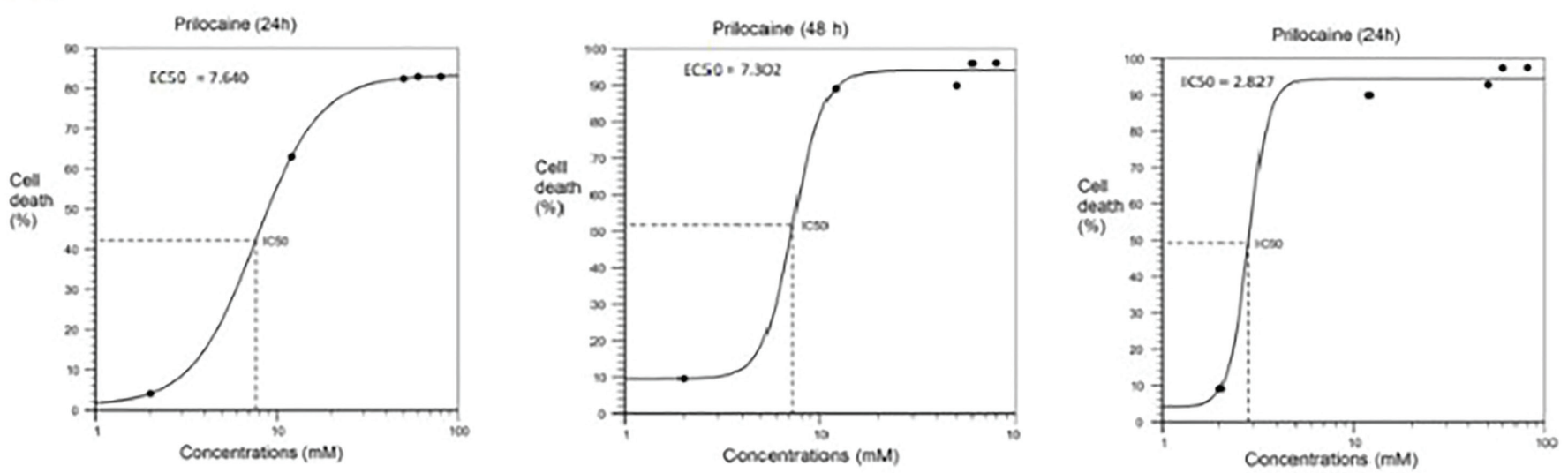

The EC50 values of lidocaine for 24, 48, and 72 hours were found as $11.67 \mathrm{mM}, 1.92 \mathrm{mM}$, and $2.11 \mathrm{mM}$, respectively. The EC50values of bupivacaine for 24, 48, and 72 hours were found as $11.4 \mathrm{mM}, 5.21 \mathrm{mN}$, and $7.3 \mathrm{mM}$, respectively. The EC50 values of prilocaine for 24, 48, and 72 hours were found as $7.64 \mathrm{mM}, 7.3 \mathrm{mM}$, and $2.83 \mathrm{mM}$, respectively (Figure 2). After $10 \mathrm{mM}$ doses, lidocaine significantly inhibited cell viability in Ishikawa cell lines according to dose and time dependent manner. After $20 \mathrm{mM}$ doses at 48 and 72 hours, approximately no cells were seen in the wells. Also, bupivacaine killed approximately almost all of the cells and there seemed no cells at 14 and $17 \mathrm{mM}$, which was the lowest value as compared with lidocaine. Also, prilocaine began to intibit Ishikawa cell at $12 \mathrm{mM}$ concentration and at the highest concentrations approximately, there were no cells. Compared to EC50 values of three compounds, we saw that at 24 hours prilocaine had the lowest value. At 48 hours, lidocaine had the lowest EC50 value, and 72 hours lidocaine and prilocaine both of them had lower values as compared to

\section{Induction of apoptosis}

The quantitative APO Percentage assay, which measured the earliest stages of apoptosis, also showed induction of apoptosis in response to 48 hours of treatment with lidocaine, bupivacaine, and prilocaine. As seen in Figure 3, lidocaine triggered apoptosis at the lowest concentrations which is $1 \mathrm{mM}$ and the highest concentrations $(50 \mathrm{mM})$ approximately all cells were undergo necrosis. Whilst, bupivacaine was effectively apoptotic at higher concentration $(14 \mathrm{mM})$, as the same for lidocaine, the highest dose $(17 \mathrm{mM})$, most of the cells underwent necrosis instead of apoptosis. Because of prilocaine also has similar powerfull apoptotic effects as lidocaine, at the lowest concentrations (2 $\mathrm{mM}$ ) almost all cells underwent apoptosis. Increased apoptosis were seen with increasing concentrations in all of three LAs in Ishikawa cell lines. At the highest concentrations, cells underwent necrosis instead of apoptotis. These data support the results that we got from cell viability assay.

Figure 3 - Apoptosis induced by local anaesthetics in endometrial cancer cells. As seen in figure at higher doses cells were gone necrosis instead as apoptosis which is supporting cell viability assay.

A

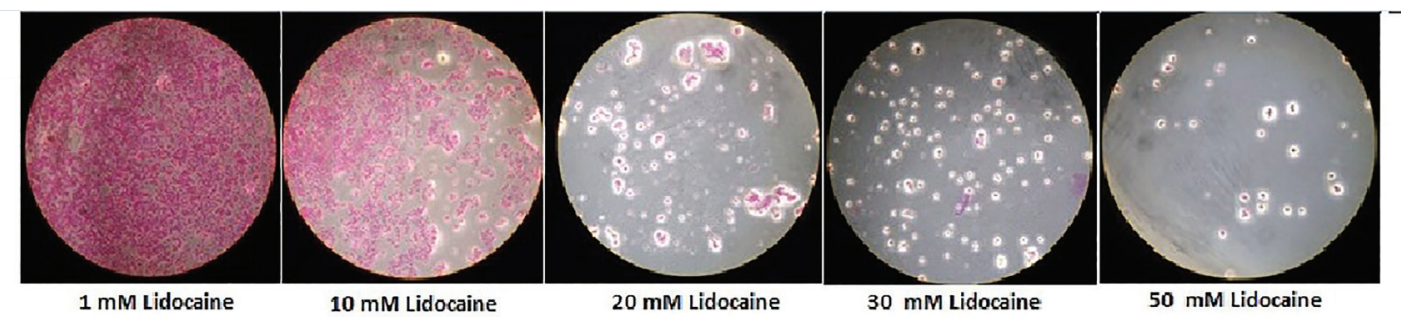

B
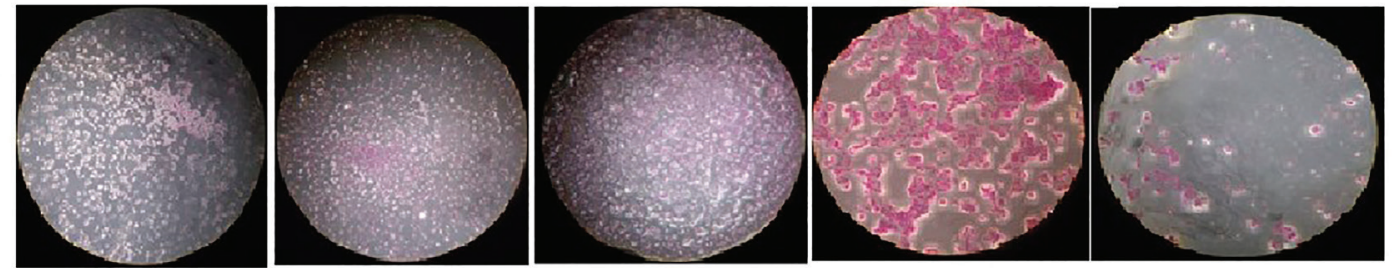

$0.02 \mathrm{mM}$ Bupivacaine

$2 \mathrm{mM}$ Bupivacaine

$12 \mathrm{mM}$ Bupivacaine

$14 \mathrm{~mm}$ Bupivacaine

$17 \mathrm{mM}$ Bupivacaine

C
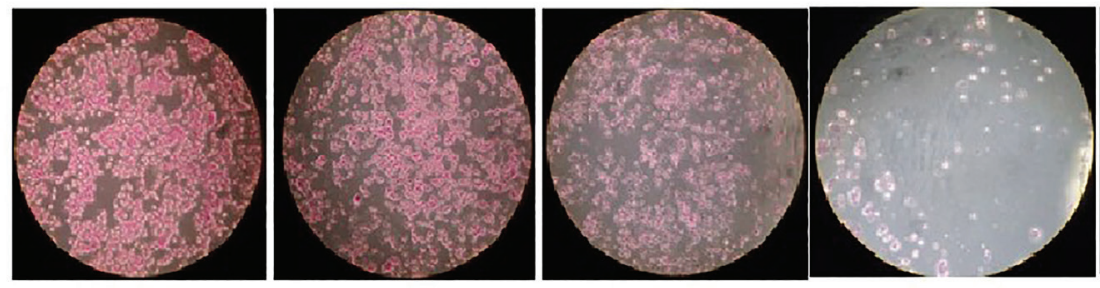

$50 \mathrm{~mm}$ Prilocaine

$60 \mathrm{mM}$ Prilocaine

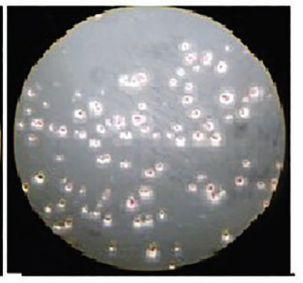

$80 \mathrm{mM}$ Prilocaine 


\section{Discussion}

In the study, it is important that all three local anesthetics show inhibitory effect on Ishikawa cells even at the lowest doses. Moreover, all three substances inhibited the viability of more than $50 \%$ in the cells at 24th, 48th, and 72 nd hours at average of $10 \mathrm{mM}$ concentration. All of substances led apoptosis in cancer cells even the lowest doses. Futhermore almost no more cells also were left when used at high doses.

Surgical resection of solid tumors can be curative, but surgery merely triggers stress responses which can induce immunsuppression. Furthermore inadvertent seeding of cancer cells may also occur during the operation. These factors may increase the risk of tumor metastasis in the perioperative period.

Although there are in-vitro studies on the mechanism of action of local anesthetics in cancer cell biology in recent years, knowledge on potential mechanisms is still limited [15]. Lidocaine is one of the most widely used local anesthetics and it effectively inhibits the invasiveness of cancer cells as in vitro in the concentrations used in surgical procedures [16]. Bupivacaine as well as lidocaine has also been shown to induce apoptosis of breast tumor cells at clinically used concentrations [14]. Prilocaine has been reported to exhibit apoptotic activity via transcriptional regulation mechanisms of specific protein or protein synthesis in osteoblastic cells [11]. Therefore apoptosisinducing activity of local anesthetics may provide additional benefits for their use that could have substantial clinical implications in cancer surgery.

Lidocaine suppresses the growth of non-small cell lung cancer (NSCLC) in a dose- and time dependent manner [17]. The ED50 (effective dose) value of lidocaine was found as 9.51 and $6.14 \mathrm{mM}$ for A549 and H520 cells (both cells were different types of non-small cell lung cancer cells) at 24th h, respectively. The total percentage of apoptosis (including early and late apoptosis) was significantly increased in the lidocaine treated group [17]. The ED50 value of lidocaine for A549 was close to our EC50 value of lidocaine at 24th h.

Lidocaine and bupivacaine inhibit the growth of both breast tumor cell lines in a dose- and time-dependent manner [14]. The authors [14] have showed that ED50 values of lidocaine and bupivacaine were significantly lower in MCF-7 cells than in MCF-10A cells. For MCF-7 cells, the ED50 of lidocaine was $4.50 \pm 0.26 \mathrm{mM}$ and that of bupivacaine was $1.30 \pm 0.11 \mathrm{mM}$ at 24 hours. The ED50 value of lidocaine and bupivacaine at 24 $\mathrm{h}$ in the study for MCF cells are much lower than our results in Ishikawa cells. Chang et al. [14] found the mean percentages of MCF-7 (human breast adenocarcinoma) cells, which were apoptotic after treatment with lidocaine $(7.4 \mathrm{mM})$ or bupivacaine (2.6 $\mathrm{mM}$ ), were $74 \%$ and $81 \%$, respectively. However, in nontumorigenic cell line MCF-10A (human mammary epithelial cell lines) treatment with lidocaine $(7.4 \mathrm{mM})$ or bupivacaine $(2.6 \mathrm{mM})$ resulted in apoptosis of $8 \%$ and $19 \%$ of the cells, respectively $(\mathrm{p}<0.001)$. They suggested that their results were in consistent with their cell viability data indicating that lidocaine and bupivacaine exhibit higher cytotoxicities in MCF-7 than in MCF-10A cells.

Chang et al. [18] demonstrated the direct effect of lidocaine and bupivacaine inhibiting cell growth and colony formation of thyroid cancer cells. Kawasaki et al. [19] showed that lidocaine suppressed neutrophil function, inhibited ATP synthesis, reduced mitochondrial membrane potential, and induced apoptosis.

The mechanisms of cell toxicity from local anesthetics have not been fully elucidated. In U937 histiocytic lymphoma cells, lidocaine induced apoptosis at concentrations below 12
$\mathrm{mM}$ and induced necrosis at concentrations above $15 \mathrm{mM}$ [20]. We also found that at the beginning concentrations from $10 \mathrm{mM}$ in 48 hours lidocaine was lethal for endometrial cancer cells. Moreover, at $30 \mathrm{mM}$ and $50 \mathrm{mM}$ concentrations almost there was no cells in the well during cell viability assay. Concurrently, we couldn't take any photograph above $20 \mathrm{mM}$, because of there was no cells in the wells. Our findings supported the research of Kamiya et. al.20 Similar observations have been reported by others [13,21,22]. Accumulating evidence suggests that local anesthetics can cause rapid neuronal death through triggering apoptosis and necrosis [21, 22]. Lee et al. [23] show that local anesthetics induce human renal cell apoptotic signaling by caspase activation and via inhibition of pro-survival signaling pathways. However, Hirata et al. [24] demonstrate that lidocaine directly inhibits tyrosine kinase activity of EGFR and suppresses the corneal epithelial cell proliferation.

In conclusion, we demonstrated that lidocaine, bupivacaine and prilocaine significantly inhibited growth of Ishikawa cell lines. Lidocaine and prilocaine were found to exert prominent apoptotic effect at lowest concentrations, but bupivacaine induced its apoptosis at higher concentrations on Ishikawa cells. The present study showed that lidocaine, bupivacaine, and prilocaine inhibits cellular growth and triggers apoptosis in Ishikawa cell lines for the first time. We also observed that LA have higher toxicity on Ishikawa cells in a dose dependent manner and the tumor cells have undergone almost complete necrosis at high doses. In the present study, we demonstrated for the first time the direct inhibitory effect of local anesthetics on Ishikawa cell lines.

There are some limitations of our study which should be considered while interpreting our results. Firstly; we have not compared the effects of the local anesthetic agents on cultured healthy endometrial cell lines. Secondly; our study has been conducted in-vitro conditions therefore in-vivo studies are necessary in order to determine the effect of these agents on endometrial cancer cells in clinical conditions.

As a result, this study has shown that three commonly used local anesthetic drugs (lidocaine, bupivakiane, prilocaine) have anti-tumoral effects on Ishikawa cells in-vitro. However, further experimental and clinical research is needed in order to clarify the effects of these agents on tumor cell biology and potential benefits of their use during cancer surgery.

Disclosures: There is no conflict of interest for all authors.

Acknowledgements: We thank to Serpil Demirag due to her contributes and comments and to Sylvia M. Bozdogan for her contributes in English editing.

Funding: The research received no specific grant from any funding agency in the public, commercial, or not-for-profit sectors.

\section{Author's contributions:}

Erel Varlik K.:This author helped conduct the study and approved the final manuscript.

Yenisey Cigdem: This author helped conduct the study, analyze the data, correct the statistics, write the manuscript. 


\section{References}

1. Johnson SM, Saint John BE, Dine AP. Local anesthetics as antimicrobial agents: a review. Surg Infect (Larchmt). 2008; 9:205-13. https://doi.org/10.1089/sur.2007.036

2. Borgeat A, Aguirre J. Update on local anesthetics. Curr Opin. Anaesthesiol. 2010; 23:466-71. https://doi.org/10.1097/ ACO.0b013e328339eef2

3. Cummings, K. C. 3rd, Xu, F., Cummings, L. C. \& Cooper, G. S. A comparison of epidural analgesia and traditional pain management effects on survival and cancer recurrence after colectomy: a population-based study. Anesthesiology. 2012; 116:797-806. https://oi. org/10.1097/ALN.0b013e31824674f6

4. Exadaktylos, A. K., Buggy, D. J., Moriarty, D. C., Mascha, E. \& Sessler, D. I. Can anesthetic technique for primary breast cancer surgery affect recurrence or metastasis? Anesthesiology. 2006; 105:660-664.https://doi.org/10.1097/00000542-200610000-00008

5. Biki, B. et al. Anesthetic technique for radical prostatectomy surgery affects cancer recurrence: a retrospective analysis. Anesthesiology. 2008; 109:180-187. https://doi.org/10.1097/ALN.0b013e31817f5b73

6. Snyder, G. L. \& Greenberg, S. Effect of anaesthetic technique and other perioperative factors on cancer recurrence. Brit. J. Anaesth. 2010; 105:106-115. https://doi.org/10.1093/bja/aeq164

7. Sakaguchi, Masahiro, Yoshihiro Kuroda, and Munetaka Hirose. "The Antiproliferative Effect of Lidocaine on Human Tongue Cancer Cells with Inhibition of the Activity of Epidermal Growth Factor Receptor. Anesthesia and Analgesia. 2006; 102:1103-7. https://oi. org/10.1213/01.ane.0000198330.84341.35

8. Tavare, Aniket N, Nicholas J. S. Perry, Laura L. Benzonana, Masao Takata, and Daqing Ma. Cancer recurrence after surgery: direct and indirect effects of anesthetic agents. Int J Cancer. 2012; 1250:1237-50. https://doi.org/10.1002/ijc.26448

9. Jiang Y, Gou H, Zhu J, Tian S, Yu L. Lidocaine inhibits the invasion and migration of TRPV6-expressing cancer cells by TRPV6 downregulation. Oncologyb Letters. 2016; 12:1164-1170. https://doi.org/10.3892/ol.2016.4709

10. Chang YC, Liu CL, Chen MJ, Hsu YW, Chen SN, Lin CH, Chen CM, Yang FM, Hu MC. Local anesthetics induce apoptosis in human breast tumor cells. Anesth Analg. 2014; 118:116-24. https://doi.org/10.1213/ANE.0b013e3182a94479

11. Nakamura K, Kido H, Morimoto Y, Morimoto H, Kobayashi S, Morikawa M, Haneji T.Prilocaine induces apoptosis in osteoblastic cells. Can J Anaesth. 1999; 46:476-82. https://doi.org/10.1007/BF03012949

12. Werdehausen R, Fazeli S, Braun S, Hermanns H, Essmann F, Hollmann MW, Bauer I, Stevens MF. Apoptosis induction by different local anaesthetics in a neuroblastoma cell line. Br J Anaesth. 2009; 103:711-8. https://doi.org/10.1093/bja/aep236

13. Perez-Castro R, Patel S, Garavito-Aguilar ZV, Rosenberg A, Recio-Pinto E, Zhang J, Blanck TJ, Xu F. Cytotoxicity of local anesthetics in human neuronal cells. Anesth Analg. 2009; 108:997-1007. https://doi.org/10.1213/ane.0b013e31819385e1

14. Chang YC, Liu CL, Chen MJ, Hsu YW, Chen SN, Lin CH, Chen CM, Yang FM, Hu MC. Local anesthetics induce apoptosis in human breast tumor cells. Anesth Analg. 2014; 118:116-24. https://doi.org/10.1213/ANE.0b013e3182a94479

15. Xuan W, Zhao H, Hankin J, Chen L, Yao S, Ma D. Local anesthetic bupivacaine induced ovarian and prostate cancer apoptotic cell death and underlying mechanisms in vitro. Sci Rep. 2016; 19(6):262-77. https://doi.org/10.1038/srep26277

16. Mammoto T, Higashiyama S, Mukai M, Mammoto A, Ayaki M, Mashimo T, Hayashi Y, Kishi Y, Nakamura H, Akedo H. Infiltration anesthetic lidocaine inhibits cancer cell invasion by modulating ectodomain shedding of heparin-binding epidermal growth factor-like growth factor (HB-EGF). J Cell Physiol. 2002; 192:351-8. https://doi.org/10.1002/jcp.10145

17. Wang HW, Wang LY, Jiang L, Tian SM, Zhong TD, Fang XM. Amide-linked local anesthetics induce apoptosis in human non-small cell lung cancer. J Thorac Dis. 2016; 8:2748-2757. https://doi.org/10.21037/jtd.2016.09.66

18. Chang YC, Hsu YC, Liu CL, Huang SY, Hu MC, Cheng SP. Local anesthetics induce apoptosis in human thyroid cancer cells through the mitogen-activated protein kinase pathway. PLoS One. 2014; 21:9. https://doi.org/10.1371/journal.pone.0089563

19. Kawasaki C, Kawasaki T, Ogata M, Sata T, Chaudry IH. Lidocaine enhances apoptosis and suppresses mitochondrial functions of human neutrophil in vitro. J Trauma. 2010; 68:401-8. https://doi.org/10.1097/TA.0b013e3181af6e56

20. Kamiya Y, Ohta K, Kaneko Y. Lidocaine-induced apoptosis and necrosis in U937 cells depending on its dosage. Biomed Res. 2005; 26:231-9. https://doi.org/10.2220/biomedres.26.231

21. Friederich P, Schmitz TP. Lidocaine-induced cell death in a human model of neuronal apoptosis. Eur J Anaesthesiol. 2002; 19:564-70. https://doi.org/10.1017/S0265021502000911

22. Werdehausen R, Braun S, Essmann F, Schulze-Osthoff K, Walczak H, Lipfert P, Stevens MF. Lidocaine induces apoptosis via the mitochondrial pathway independently of death receptor signaling. Anesthesiology. 2007; 107:136-43. https://doi.org/10.1097/01. anes.0000268389.39436.66

23. Lee HT, Xu H, Siegel CD, Krichevsky IE. Local anesthetics induce human renal cell apoptosis. Am J Nephrol. 2003; 23:129-39. https:// doi.org/10.1159/000069304

24. Hirata M, Sakaguchi M, Mochida C, Sotozono C, Kageyama K, Kuroda Y, Hirose M. Lidocaine inhibits tyrosine kinase activity of the epidermal growth factor receptor and suppresses proliferation of corneal epithelial cells. Anesthesiology. 2004; 100:1206-10. https:// doi.org/10.1097/00000542-200405000-00024 